SCIREA Journal of Fisheries

http://www.scirea.org/journal/Fisheries

July 28, 2021

Volume 2, Issue 1, February 2021

\title{
Growth performance, feed conversion and gross margin analysis of Nile tilapia (Oreochromis niloticus) in Valley Dam Based Floating Cages in Semi-Arid Karamoja Sub- Region of Uganda
}

Constantine Chobet Ondhoro*1, ${ }^{2}$, Moses Ndugua ${ }^{1}$, Paul Boma ${ }^{1}$, Charles Byaruhanga ${ }^{1}$, Faustine Odeke', George Egayu ${ }^{1}$, Emmanuel Ojan ${ }^{1}$, Gerald Osipa ${ }^{2}$, Ismail Kagolola ${ }^{2} \&$ Paul Okullo ${ }^{1}$

${ }^{1}$ National Agricultural Research Organization. Nabuin Zonal Agricultural Research and Development Institute. P.O.Box 132, Moroto (Uganda)

${ }^{2}$ National Agricultural Research Organization. Buginyanya Zonal Agricultural Research and Development Institute. P.O.Box 1356, Mbale (Uganda)

*Corresponding author: Constantine Chobet Ondhoro, ${ }^{2}$ National Agricultural Research Organization. Buginyanya Zonal Agricultural Research and Development Institute. P.O.Box 1356, Mbale (Uganda).

Email: occonstantine88@gmail.com

Telephone: +256782228987 .

\begin{abstract}
Growth indices, environmental parameters and profitability of aquaculture practices facilitate policy development for regulation of commercial aquaculture activities in public waters bodies. An experiment to evaluate growth performance, feed conversion, gross profit and
\end{abstract}


environmental impacts of Nile tilapia culture under four different density treatments (A,B,C \&D) using sinking compound feeds, was conducted in floating net cages placed in a valley dam. The four treatments were each assigned to an $8 \mathrm{~m}^{3}$ floating cage in duplicate for five months. Highest mean body mass of $311.49 \pm 114.6 \mathrm{~g}$ was obtained from treatment A which had lowest stocking density while treatment $\mathrm{C}$ registered the lowest body mass of $138 \pm 40.2 \mathrm{~g}$. Highest growth rate of $2.6 \% \mathrm{BWday}^{-1}$ while the lowest specific growth value of $2.0 \%$ BWday $^{-1}$ was recorded in treatment $\mathrm{C}$, while the best condition of 1.9 and worst of 0.6 were recorded in treatments $\mathrm{B}$ and $\mathrm{D}$, respectively. The best feed conversion ratio $(1.5 \mathrm{~kg})$ and highest profitability of Uganda shillings (Ushs) 945,086 while the worst feed conversion of $3.3 \mathrm{~kg}$ and lowest profitability of 69,033 Ushs were obtained from treatments A and D respectively. Water quality did not $(\mathrm{P}>0.05)$ influence fish growth significantly. The study reveals the possibility of commercial aquaculture venture in valley dams in Karamoja subregion.

Keywords: Specific growth rate, fish condition, FCR, profitability

\section{INTRODUCTION}

Nile tilapia (Oreochromis niloticus) constitutes the largest proportion of farmed fish species in Uganda and is highly favored for floating cage fish culture in the world (Ashley, 2007; Bassy and Ajah, 2010). Its biological and ecological flexibility renders it highly suitable species for intensive culture across the different production systems (cages, earthen ponds, and concrete tanks (Bortone, 2003). Farming of the species in valley dams is a nascent undertaking in Uganda, with key requisite information such as growth rates, yields, food conversion ratio and environmental impacts being tawdrily scarce. Moreover, cage fish culture in public large water bodies such as dams, lakes and rivers, etc; require appropriate regulatory policies to mitigate pollution and guarantee sustainability. However, formulation of such policies also requires technical information especially appropriate stocking densities to safeguard against water pollution resulting from high waste generation from within the system.

In Karamoja sub-region, a number of valley dams were originally placed for crop irrigation and watering livestock. The introduction of cage fish farming into these dams is an 
afterthought undertaking to compliment agricultural output of the dam in availing the much needed fish protein to vulnerable groups in a hard-to-reach area (Bortone, 2003). The success of the introduction of fish farming in valley dams requires strong technical guidelines to safeguard environmental quality and make the enterprise economically sound and environmentally sustainable.

Arechek valley dam is located in Napaki district in semi arid Karamoja sub-region of Uganda, characterized by erratic rainfall patterns averaging 300- $1200 \mathrm{~mm}$ annually (Cullis, 2018). The region is sparsely populated with humans due to high level of infant and maternal mortalities, which stands at 64 deaths per 1000 live birth (Atukunda et al., 2018). The high infant and maternal mortalities are motivated by among others malnutrition (Cullis, 2018). The area largely rely on cattle products such as milk and beef but this of late has become insufficient in quantity, unreliable and nutritionally inferior compared to fish (Atukunda et al., 2018).

Amidst the persistent prolonged drought, inadequate food supply, malnutrition, the Karamoja community has no sustainable source of food fish, yet fish protein is known to be nutritious and superior in terms of supply of essential amino acid (lysine) and omega-3 fatty acid (FAO, 2017). To ensure sustained supply of food fish to this region there is urgent need through promotion of fish farming to augment the use of the valley dams and sustain supply of fish to the community. Sustainability of fish farming in this area requires knowledge of appropriate stocking density, growth rates, yield levels and the feed conversion ratio of each feed types used but these are still lacking. The main purpose of this study was therefore, to provide Nile tilapia cage culture information to guide future production and policy formulation towards sustainability.

\section{MATERIALS AND METHODS}

\section{Study area}

The study was conducted in a valley dam located in Arechek village, Napak district, Karamoja sub-region, North Eastern Uganda (Fig. 1). 


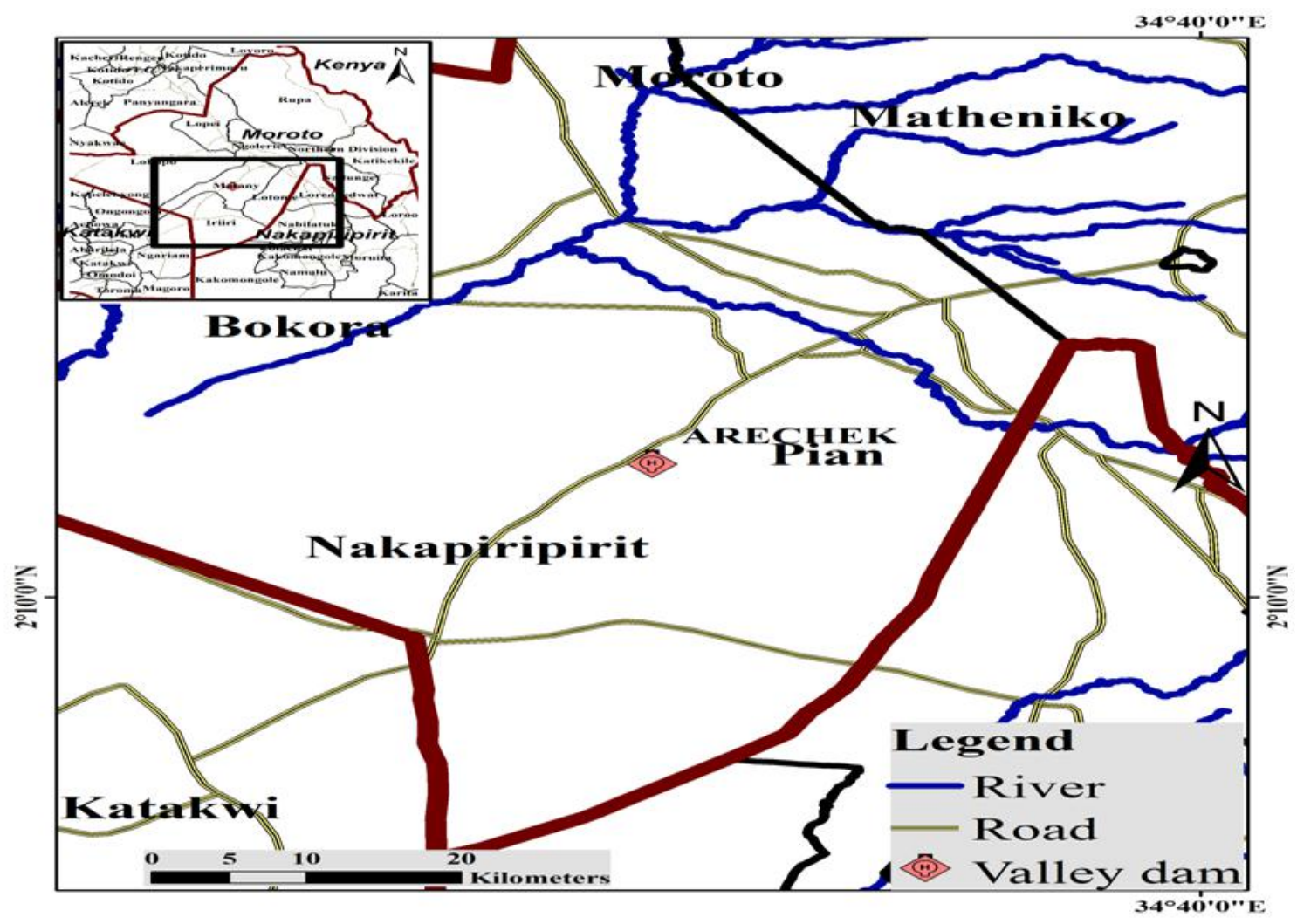

Figure 1

\section{Experimental materials and design}

Eight floating cages each $2 \times 2 \times 2$ meters labeled, with each corresponding to a given stocking density, constituted experimental units. The cages were assigned treatments of different stocking densities as follows; Nabuin cage A (100 fishm $\left.{ }^{-3}\right)$; Nabuin cage B (150 fishm $\mathrm{fs}^{-3}$ ); Nabuin cage C (200 fishm $\left.{ }^{-3}\right)$; Nabuin cage D $\left(250 \mathrm{fishm}^{-3}\right)$. All the cages were staged at least 0.25 nautical miles away from the dam embankment to a mean water depth of at least 5-7 meters.

\section{Feeding and sampling regimes}

The fish were fed thrice (0830-0930hrs, 1230-1330hrs and 1630-1730hrs) daily, for a period of three months, after which the feeding frequency was reduced to two for the remaining growth period. The fish were fed to satiation according to observed fish feeding response. The amount of feed weighed per day for each cage/units was recorded. The quantity fed to the fish in respective cages was also recorded. At least 30-50 fish in each cage were randomly sampled on a monthly basis by partially lifting the cage netting and harvesting fish with a scoop net. The cage nets were cleaned monthly during every sampling regime. Fish 
sampling to assess growth, feed conversion ratio and environmental impact was done monthly.

\section{Determination of water quality}

The water quality measurements were done on-spot between $0800 \mathrm{hrs}$ and $0900 \mathrm{hrs}$ on each sampling day, using a multi-parameter water quality test meter, model Eco-Sense DO200A. Reading for each parameter was taken from two locations (in and outside cage). The parameters taken were temperature (degrees Celsius), Dissolved oxygen (ppm) and $\mathrm{pH}$.

\section{Feed analysis}

Proximate nutrient composition of the commercial feeds was carried out by ARDC Kajjansi, using AOAC (1995; 2005) standard methods for various nutritional components, which included: moisture, crude protein, crude lipid, crude fibre, and ash.

\section{Determination of fish growth}

\section{Specific Growth Rate, SGR}

The specific growth rate for each treatment group was calculated as:

SGR $(\%$ body weight gain/day $)=[\ln W f-\ln W i] X 100$

\section{Time}

Where, $\ln \mathrm{Wf}=$ the natural logarithm of the mean final weight $(\mathrm{g}), \ln \mathrm{Wi}=$ the natural logarithm of the mean initial weight $(\mathrm{g}), \mathrm{t}=$ time (days of growth) between $\ln \mathrm{Wf}$ and $\ln \mathrm{Wi}$ (Ricker, 1975).

\section{Relative condition Factor, Kn}

To compare condition among treatments and for the generation of predictive models of fish condition, relative condition factor of Nile tilapia, was calculated as the ratio of observed individual fish weight to expected weight of an individual of a given length, applying the formula: $\mathrm{K}_{\mathrm{n}}=\mathrm{W}_{\mathrm{i}} / \mathrm{aL}_{\mathrm{i}}^{\mathrm{b}}$ (Le Cren, 1951; Efitre et al., 2009; Ondhoro et al., 2016). Where $\mathrm{W}_{\mathrm{i}}$ is observed individual fish weight, $\mathrm{L}_{\mathrm{i}}$ is observed individual fish total length, and $\mathrm{a}$ and $\mathrm{b}$ are species-specific constants.

\section{Food conversion ratio}

The quantity of feed used to produce a unit mass of fish was computed as; 
$\mathrm{K} /$ (B-A), where, $\mathrm{K}$ implies amount of feed consumed by the fish while A and $\mathrm{B}$ are the initial and final fish body mass respectively.

\section{Gross margin analysis}

Gross margin was computed using simple farm budgetary technique as the difference between gross values of fish produced and total variable cost during the experiment. The model below was applied;

Gross profit $(\mathrm{GP})=$ Total Revenue - Total Variable Costs (TVC)

\section{Total harvest}

After five months of experimental growth, a sample population of 50 fish was first drawn from each cage for extract of monthly biometric data. Water quality data was also collected from in and outside each cage. From each cage, all the fish were harvested and collectively weighed to obtain the total weight obtained per cage, which then pooled per each stocking density treatment.

\section{Data analysis}

Data generated from each treatment replicates were pooled and analyzed per treatment. Differences in growth performance were compared using univariate analysis of variance (ANOVA). To explore the effects of water quality and stocking density on fish growth, multiple regression analysis of respective growth indices against water quality parameters was performed, by fitting fish weight/body mass and relative condition factor $\left(\mathrm{K}_{\mathrm{n}}\right)$ against water quality variables and stocking density. Mean feed conversion ratios and the profitability of applying the different fish stocking densities were computed using simple budgetary tool. Statistical analysis was done using SPSS for windows version 21 at $0.05 \%$ level of significance as described by Field and Wilcox (2019).

\section{RESULTS}

The proximate nutrient composition of the feed used is presented in (table 1).

Proximate nutrient composition of experimental feeds

\begin{tabular}{cc}
\hline Component & Proportion \\
\hline Dry matter (\%) & 91.6 \\
\hline
\end{tabular}




\section{Fish growth}

In five months growth period, mean final fish body mass ( \pm stdev) in different treatments were $311.49 \pm 114.6 \mathrm{~g}, 204.8 \pm 30.5 \mathrm{~g} ; 138 \pm 40.2 \mathrm{~g}$, and $153.3 \pm 68.8 \mathrm{~g}$ from initial of 1.5 ; 1.6 , 1.7, and1.6 $\mathrm{g}$ in cages $\mathrm{A}, \mathrm{B}, \mathrm{C}$ and $\mathrm{D}$ respectively. While the mean fish total lengths were $23.29 \pm 2.55,17.5 \pm 5.5,15.6 \pm 15.6,19.4 \pm 3.02 \mathrm{~cm}$, from $5.6 \pm 1.0,4.9 \pm 1.2,4.5 \pm 1.2$ and $4.9 \pm 0.7$ $\mathrm{cm}$ in treatments $\mathrm{A}, \mathrm{B}, \mathrm{C}$ and $\mathrm{D}$ respectively. The relationship between fish length and body mass in treatments $A$ and $B$ was negative allometry, with ' $b$ ' values being $2.85 ; R^{2}=0.884$ and 2.82; $R^{2}=0.970$, while in treatments $C$ and $D$, was positive allometry; $b=3.3 ; R^{2}=$ 0.959 and $\mathrm{b}=3.3 ; \mathrm{R}^{2}=0.899$ respectively. The trend in change of weight in the respective stocking densities is presented below (Fig. 2).

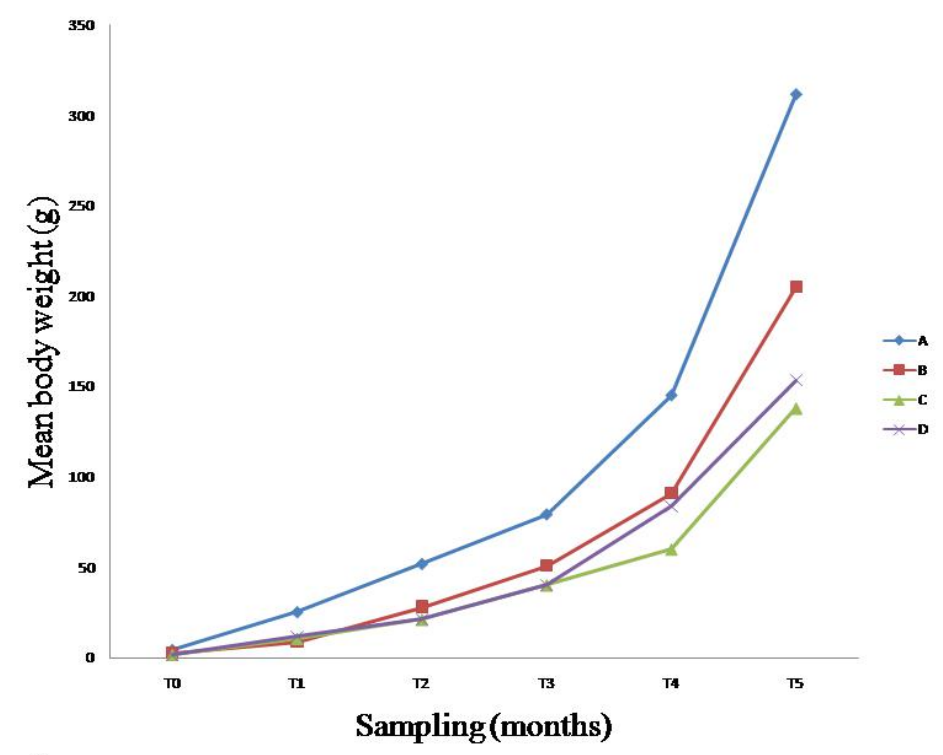

Figure 2

\section{Specific growth rate}


Fish in all treatments experienced exponential growth rate of 4.1 to $6.6 \% \mathrm{BWd}^{-1}$, with cages $\mathrm{C}$ and $\mathrm{D}$ which had much higher stocking densities growing at 6.1 and $6.5 \% \mathrm{BWd}^{-1}$ respectively, much faster than individuals in cages $\mathrm{A}$ and $\mathrm{B}$, which grew at 4.1 and 6.0 respectively within the first month of growth. Growth rate reduced across all treatments as time increased, but the reduction in growth was much more pronounced in treatments $\mathrm{C}$ and $\mathrm{D}$ with higher stocking densities. Thus the final growth rate at the fifth month was 2.6, 2.7, 2.0 and $2.5 \% \mathrm{BWd}^{-1}$ in treatments $\mathrm{A}, \mathrm{B}, \mathrm{C}$ and $\mathrm{D}$, respectively. By the closure of the experiment in the fifth month, the curves for treatments C and D had leveled off, meaning, the fish in these units were growing at decreasing rates. While the individuals in treatments A and $\mathrm{B}$ which had lower stocking densities were still growing at increasing rate as indicated by the growth curves (Fig. 3)

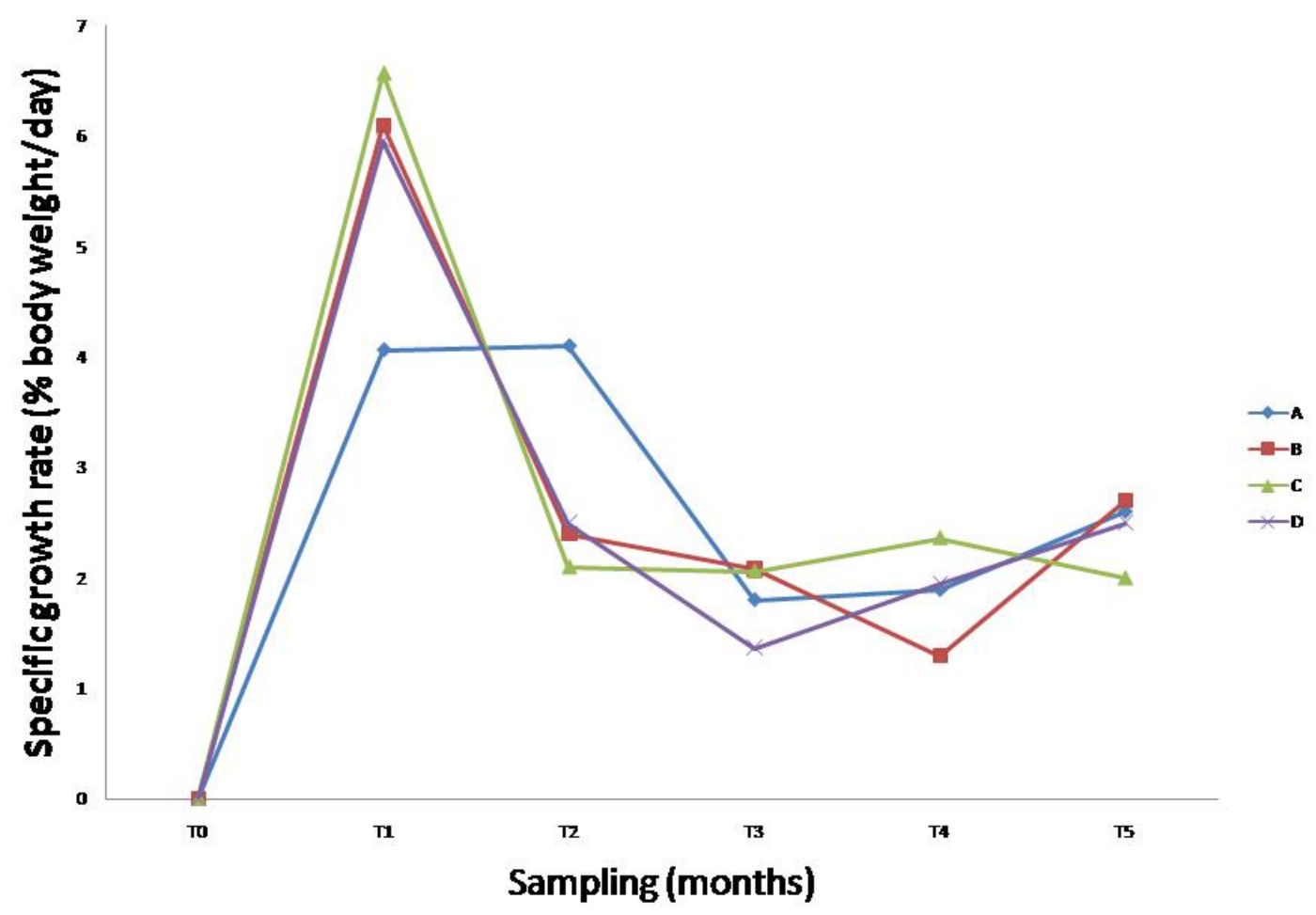

Figure 3

\section{Fish condition}

Mean relative condition $\left(\mathrm{K}_{\mathrm{n}}\right)$ for the respective treatments $(\mathrm{P}<0.05)$ were $( \pm$ stdev $) 1.08 \pm 0.08$, $1.91 \pm 0.13,0.79 \pm 0.08$ and $0.65 \pm 0.08$ in treatments A, B, C and D, respectively (Fig. 4). 


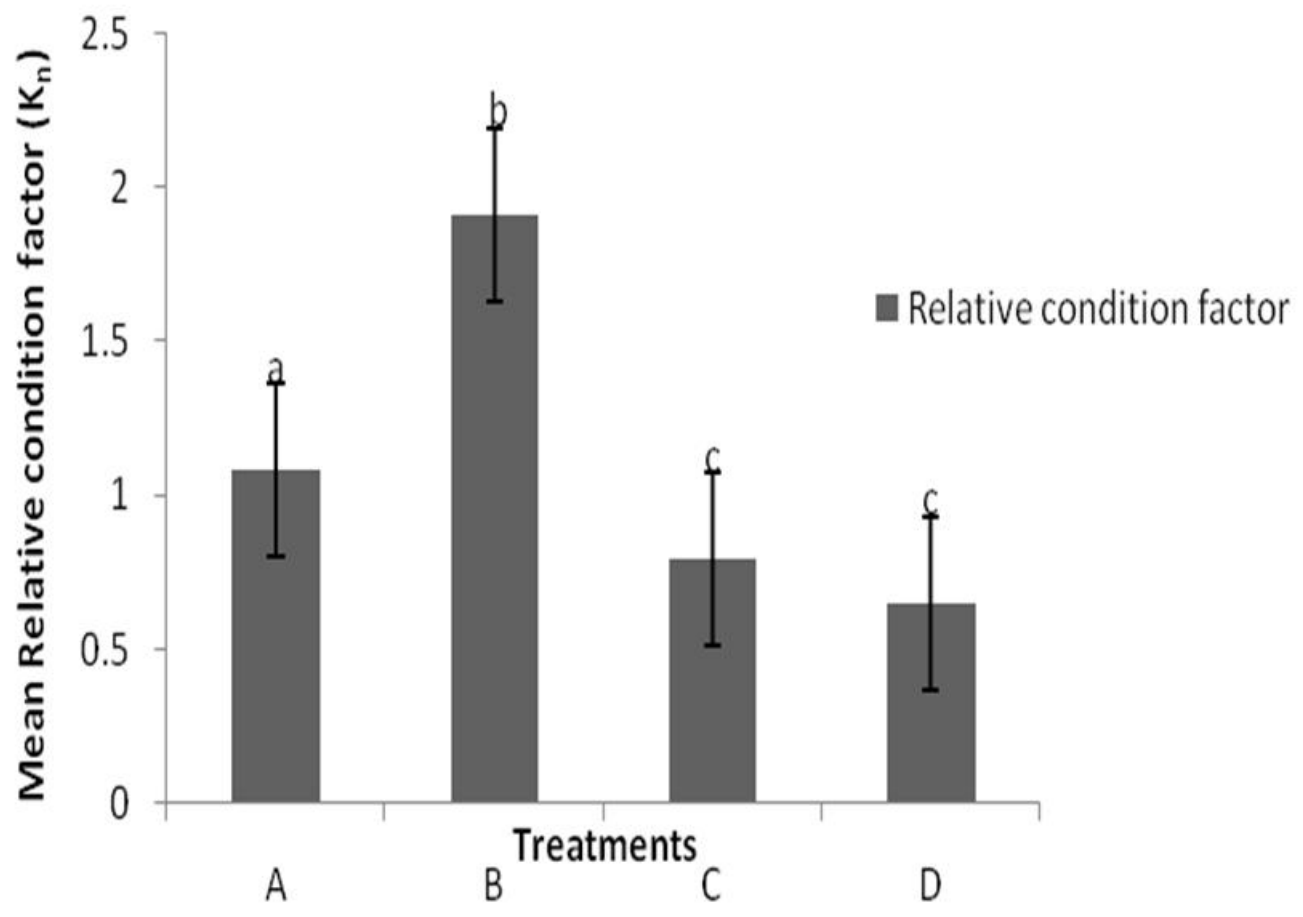

Figure 4

\section{Feed conversion ratio, gross profit and associated growth parameters}

There was very significant $(\mathrm{P}<0.05)$ differences in feed conversion among the treatments. The best feed conversion value of $1.5 \mathrm{~kg}$ of feed used to produce a kilogram of wet fish was recorded in treatment $\mathrm{A}$, while treatment $\mathrm{B}$ recorded $2.6 \mathrm{~kg}$ and treatments $\mathrm{C}$ and $\mathrm{D}$ used 3.3 and $3.2 \mathrm{~kg}$ of feed to produce a kilogram of fish respectively.

Fish survival was also highly significant $(\mathrm{P}<0.05)$ among the treatments. Treatment $\mathrm{D}$ had the highest survival of $90 \%$ of the individuals initially stocked surviving to harvest. Treatments B and $\mathrm{C}$ were not significantly different from each other, with each having 79 and $78 \%$ survival respectively, while treatment A registered the lowest survival of $67 \%$ in five months.

Considering the cost of producing table fish using the respective stocking densities, more cost was incurred in treatment $\mathrm{D}$ and hence the treatment was the least profitable. Treatments $\mathrm{B}$ and $\mathrm{C}$ incurred higher costs while the lowest cost was incurred in producing table fish in treatment $\mathrm{A}$, hence making the treatment the most profitable with the highest gross profit (Table 2). 


\begin{tabular}{|c|c|c|c|c|c|c|c|c|c|c|c|}
\hline \multirow[b]{2}{*}{$\begin{array}{l}\text { Stockin } \\
\text { g } \\
\text { density } \\
\text { (fishm } \\
\text { 3) }\end{array}$} & \multirow[b]{2}{*}{$\begin{array}{l}\text { Initial } \\
\text { mean } \\
\text { weight } \\
(\mathrm{g})\end{array}$} & \multirow[b]{2}{*}{$\begin{array}{c}\text { Tot } \\
\text { al } \\
\text { nu } \\
\text { mbe } \\
\text { r }\end{array}$} & \multirow[b]{2}{*}{$\begin{array}{c}\text { Initial } \\
\text { bioma } \\
\text { ss } \\
(\mathbf{K g})\end{array}$} & \multirow[b]{2}{*}{$\begin{array}{c}\text { Final } \\
\text { mean } \\
\text { Weigh } \\
\text { t (g) }\end{array}$} & \multirow[b]{2}{*}{$\begin{array}{c}\text { Mean } \\
\text { final } \\
\text { numb } \\
\text { er }\end{array}$} & \multirow[b]{2}{*}{$\begin{array}{l}\mathbf{M} \\
\mathbf{e} \\
\mathbf{a} \\
\mathbf{n} \\
\mathbf{F} \\
\mathbf{C} \\
\mathbf{R} \\
\end{array}$} & \multirow[b]{2}{*}{$\begin{array}{c}\text { Total } \\
\text { Survi } \\
\text { val } \\
(\%)\end{array}$} & \multirow[b]{2}{*}{$\begin{array}{c}\text { Final } \\
\text { biom } \\
\text { ass } \\
\text { (kg) }\end{array}$} & \multirow[b]{2}{*}{$\begin{array}{c}\text { Total } \\
\text { variabl } \\
\text { e } \\
\text { Cost(Us } \\
\text { hs) }\end{array}$} & \multirow[b]{2}{*}{$\begin{array}{c}\text { Total } \\
\text { reven } \\
\text { ue } \\
\text { (Ushs) }\end{array}$} & \multirow[b]{2}{*}{$\begin{array}{c}\text { Gross } \\
\text { profit } \\
\text { (Ushs } \\
\text { ) }\end{array}$} \\
\hline & & & & & & & & & & & \\
\hline $\begin{array}{c}\text { (A) } 100 \\
\mathrm{X} 8\end{array}$ & 1.5 & $\begin{array}{c}800 . \\
0\end{array}$ & 1.2 & $\begin{array}{c}311.49 \\
\pm 114.6 \\
\mathrm{a}\end{array}$ & 536 & $\begin{array}{l}1 . \\
5\end{array}$ & $67^{\mathrm{a}}$ & $\begin{array}{c}166.9 \\
5^{a}\end{array}$ & $\underset{\mathrm{a}}{724,500}$ & $\begin{array}{c}1,669 \\
586\end{array}$ & $\begin{array}{c}945,0 \\
86^{\mathrm{a}}\end{array}$ \\
\hline $\begin{array}{c}\text { (B) } 150 \\
\mathrm{X} 8\end{array}$ & 1.6 & $\begin{array}{l}120 \\
0.0\end{array}$ & 1.92 & $\begin{array}{c}204.8^{ \pm} \\
30.5^{\mathrm{b}}\end{array}$ & 943 & $\begin{array}{c}2 . \\
6\end{array}$ & $79^{b}$ & $\begin{array}{c}193.1 \\
1^{\mathrm{b}}\end{array}$ & $\begin{array}{c}1,491,9 \\
44^{\mathrm{b}}\end{array}$ & $\begin{array}{c}1,931 \\
106\end{array}$ & $\begin{array}{c}439,1 \\
62^{\mathrm{b}}\end{array}$ \\
\hline $\begin{array}{c}\text { (C) } 200 \\
\text { X8 }\end{array}$ & 1.7 & $\begin{array}{l}160 \\
0.0\end{array}$ & 2.72 & $\begin{array}{c}138 \pm 4 \\
0.2^{\mathrm{c}}\end{array}$ & 1254 & $\begin{array}{l}3 . \\
3\end{array}$ & $78^{\mathrm{b}}$ & $\begin{array}{c}173.0 \\
1^{\mathrm{b}}\end{array}$ & $\begin{array}{c}1,661,1 \\
18^{\mathrm{c}}\end{array}$ & $\begin{array}{c}1,730 \\
151\end{array}$ & $\begin{array}{c}69,03 \\
3^{\mathrm{c}}\end{array}$ \\
\hline $\begin{array}{c}\text { (D) } 250 \\
\mathrm{X} 8\end{array}$ & 1.6 & $\begin{array}{c}200 \\
0.0\end{array}$ & 3.2 & $\begin{array}{c}153.3 \pm \\
68.8^{\mathrm{d}}\end{array}$ & 1805 & $\begin{array}{l}3 . \\
2\end{array}$ & $90^{\mathrm{c}}$ & $\begin{array}{c}276.7 \\
0^{c}\end{array}$ & $\begin{array}{c}2,637,3 \\
21^{\mathrm{d}}\end{array}$ & $\begin{array}{c}2,767 \\
065\end{array}$ & $\begin{array}{c}129,7 \\
44^{\mathrm{d}}\end{array}$ \\
\hline
\end{tabular}

Table 2 Feed conversion ratio and gross profit of Nile tilapia fed on sinking feeds in Arechek valley dam, Napaki district. The treatments were distributed in experiments units (cages A, B, C and D). Experiment A, B, C and D represent the different stocking densities 100, 150, 200 and 250 fishm $^{-3}$ respectively. Different letters against each set of values signify significant $(\mathrm{P}<0.05)$ differences within particular columns.

\section{Effects of water quality and stocking density on relative fish condition}

Mean water quality parameters did not vary significantly among treatments $(P>0.05)$. The observed variation in mean growth parameters especially relative condition factor among treatments was not influenced by water quality parameters $K_{n}, F(4,59)=1.849, P>0.05, R^{2}$ $=0.111)$. The variation in mean relative condition was mainly due to the effects of stocking density $(\mathrm{P}<0.05)$ (Table 3).

Table 3 Mean levels \pm Stdev of the physico-chemical water quality parameters in the different cage culture treatments. The treatments were distributed in experiments units (cages A, B, C and D). Experiment A, B, C and D represent the different stocking densities $100,150,200$ and 250 fishm $^{-3}$ respectively. 


\begin{tabular}{lllllll}
\hline Water quality parameters & \multicolumn{2}{l}{ Levels in different treatments } & & $\begin{array}{l}\text { Benchmark for } \\
\text { fresh water fish } \\
\text { culture }\end{array}$ \\
& & A & B & C & D & \\
\hline Dissolved oxygen $\left(\mathrm{mgL}^{-1}\right)$ & $4.8 \pm 1.1$ & $4.8 \pm 1.2$ & $4.9 \pm 1.3$ & $4.9 \pm 1.3$ & $\geq 5(\mathrm{Boyd}, 1998)$ \\
Water Temperature $\left({ }^{\circ} \mathrm{C}\right)$ & $25.5 \pm 1.3$ & $25.4 \pm 1.5$ & $25.3 \pm 1.6$ & $25.3 \pm 1.7$ & $25-30(\mathrm{Boyd}, 1998)$ \\
Hydrogen potential $(\mathrm{pH})$ & $7.3 \pm 0.4$ & $7.3 \pm 0.4$ & $7.3 \pm 0.4$ & $7.3 \pm 0.4$ & $6.5-8.5$ (Boyd, 1998) \\
\hline
\end{tabular}

\section{DISCUSSION}

\section{Better growth and condition indices under low fish stocking densities}

The results in Fig. 2 show that lower stocking density of 100-150 fism ${ }^{-3}$ could be optimum for culture of Nile tilapia in valley dams with limited water exchange. The fish in all the stocking density treatments experienced exponential growth at early age, reflective of smaller size of the fish at stocking, creating more space for individuals to feed and grow normally. However, with increase in fish biomass against the fixed volume of cages (experimental units), growth continued but at decreasing rate across all treatments. The distinction became more apparent between the second and fourth months of growth, whereby, even with slight increase in the growth rates of individuals in treatments $\mathrm{C}$ and $\mathrm{D}$, this could not result in improved body mass compared to the counter parts in A and B treatments. At the end of the fifth month, fish in treatment $\mathrm{C}$ continued to grow at decreasing rate as the rest of the treatments grew at increasing rate, an indication that the system had reached carrying capacity in treatment $\mathrm{C}$. Studies with other fish species have also demonstrated significant negative effects of treatment densities on fish growth. Iwrin et al. (1999) discovered that fish held at highest stocking densities showed lower growth rates and mean weights than those held at lower stocking densities in Turbot growth rearing experiments. Similarly, Saillant et al. (2003) demonstrated rapid decline in growth rates with increased stocking density of European Sea bass. Other species that have showed similar growth reactions in response to increased stocking density are; Rainbow trout (Holm et al., 1990; Ellis et al., 2002); Atlantic cod (Lambert and Dutil, 2001).

Elsewhere, studies have also showed that, whereas, increased stocking density has negative effects on growth, the effects vary with the stage of development of the fish. For example Greaves and Tuene (2001) found that small juveniles of Atlantic halibut (Hippoglossus 
Hippoglossus) stocked in higher densities grew better than those under lower stocking densities contrary to more mature individuals. Tolerance to increasing stocking density and its effects on life stage have been found with the African catfish (Clarias gariepinus) and flat fish; as such larvae of these species survive and grow better at higher stocking density. However, negative effects have been reported with increase in age, reflected by decreased growth rates (Hecht and Appelbaum, 1988; Haylor, 1991; Hossain et al., 1998). Likewise, the exponential growth rates across all treatments during the first month of this study also shows the plastic nature of Nile tilapia growth response to stocking density, confirming that the fish thrives better at higher stocking density during fry to fingerling stages. But this higher growth rate soon starts to reduce with increased stocking density as the fish approaches juvenile to adult stages. One would argue that at juvenile to adult stages, the appropriation of energy becomes more complex given the reproductive and somatic growth demands (Mortuza and Al-Misned, 2013).

Other than growth rates and body mass indices, the distinction in well-being of the stock becomes even more clearer in reference to relative condition factor as such fish in treatments $\mathrm{A}$ and $\mathrm{B}$ which had lower stocking densities also had better condition indices above the value of one contrary to the counterparts in treatments $\mathrm{C}$ and $\mathrm{D}$ which both had condition index below one. Stocking density has been showed to have negative effects on fish condition and the general welfare of individuals. Biswas et al. (2011) demonstrated that fish will normally attain better condition due to reduced competition under lower stocking density.

Considering all growth parameters (body mass, growth rates and condition index), there were indicators of better growth performance in treatments with lower stocking density contrary to those with higher stocking density. Similarly, Raman et al. (2017) reported an inverse relationship between stocking density and growth parameters of cage farmed Stinging catfish, Heteropneustes fossilis. The former is also in conformity with the finding of Mondal and Chakravarty (2016) that qualify growth potential of a given species to an important selection criterion for culture organism. Similarly, Mondal and Chakravarty (2016) obtained final body weight of $321 \mathrm{~g}$ with daily growth weight of 1.7 gday $^{-3}$ in six months at pond stocking density of 40,000 fishha ${ }^{-1}$. Likewise, whereas, ponds are often operated at much lower stocking densities than cages, every production system has a limit beyond which more individuals would either be lethal or economically unsustainable to operate (FAO, 2009; Sadek, 2013).

\section{Better feed conversion and higher profitability under lower stocking density}


It is stated that optimum stocking density avails fish stocks conducive environment, free of physiological stress since water quality parameters remain plausible, providing the organisms with the opportunity to benefit from food administered through good feed intake, assimilation and hence better conversion to somatic growth. As seen in treatments A and B, lower stocking density could have enabled the fish to maximize benefits from the feeds, resulting into lower/better values of feed conversion of 1.5 and $2.6 \mathrm{~kg}$ feed for a kilogram of fish produced.

Resulting from high feed conversion and better growth indices, the profitability of fish reared in treatments A and B which had lower stocking density was also much higher than those of treatments $\mathrm{C}$ and $\mathrm{D}$ which had high stocking densities. Contrary to this development, the highest fish survival was obtained in the highest stocking density in treatment $\mathrm{D}$, while treatments $\mathrm{B}$ and $\mathrm{C}$ had almost equal survival rates compared to treatment $\mathrm{A}$ with the lowest survival rates. Lowest survival in treatment A with the lowest stocking density represents an isolated incidence that could have emanated from mortality due to handling stress, escapes or bird predation but not due to density dependent factors. The influence of density dependent mortality could have manifested in water quality which fortunately was within normal ranges as described by Barton and Iwama (1991); Boyd (1998); Viadero (2005). However, whereas, treatment A had the lowest fish survival rates, the combined effects of better growth indices and higher feed conversion made the treatment more profitable to operate than those with higher stocking density and higher survival rates. This study reveals that "provided the stocking density is not below ascertain minimum the number of fish in the system does not real matter in determining its profitability but rather the feed conversion ratio and somatic growth rate" therefore, the faster the fish attains bigger body mass using smallest possible quantity of feed the better. This also implies that whereas, fish survival is important in aquaculture, the feed conversion and growth rates determine the size at harvest and that size is an important market factor in aquaculture business. Having too many small sized fish in the system may not be as important as having fewer bigger ones. When fish are over stocked, the stock highly risks being exposed to crowding; un-necessary struggles for feed and in this process, a number of individuals get wounded and are subjected to opportunistic infections that can easily lead to an outbreak of diseases. Furthermore, because of crowding and struggling for food, individuals are often exposed to physiological stress, feed wastage, thereby, leading to lower conversion ratio, slow growth, smaller somatic sizes and eventual high cost of production and lower profitability. Similarly, Gonella (2003); Bassy and Ajah 
(2010) demonstrated the link between crowding of fish and high waste generation in the system to high metabolism which pollute the rearing environment, causing stress and consequently poor growth, manifested in poor condition, poor feed conversion and low profitability.

\section{Water quality within normal range but below optimum levels.}

The importance of physico-chemical water quality parameters on fish growth cannot be underestimated. The parameters monitored during the experiment period remained within normal range for Nile tilapia cultivation (Boyd, 1998; Viadero, 2005; Bassy and Ajah, 2010).

Whereas dissolved oxygen and water temperature were below optimum, their effects did not vary with treatments. The oxygen demand for cichlids is $5 \mathrm{mgL}^{-1}$ but this group can tolerate a much lower levels and consequently high temperature of up to $30^{\circ} \mathrm{C}$ (Swift, 1988; Boyd, 1998; Lloret et al., 2002; Viadero, 2005).

Dissolved oxygen is a critical factor in intensive fish culture and its availability determines the success or failure of a fish culture venture. The optimum dissolved oxygen, temperature and $\mathrm{PH}$ for freshwater fish culture is $5 \mathrm{mgL}^{-3 ;} 27^{\circ} \mathrm{C}$ and 7 respectively.

Deviation from optimum levels transit through tolerable, stress and lethal levels. For example; Alabaster and Lloyd (1980) indicated that reduction in dissolved oxygen concentration of $50 \%$ air saturation could lead to reduced appetite and poor feed conversion and eventual poor growth, even when all other factors remain favorable. Similarly, regarding treatments with higher stocking densities in $\mathrm{C}$ and $\mathrm{D}$, the crowd condition could have created oxygen stress that affected feed intake and general metabolic conditions of the fish. This in the long run lead to poor growth as a result of stressful conditions.

\section{CONCLUSION}

Although growth, growth rates and fish condition data are widely available in fish databases, the current findings open a unique opportunity for proving to the world the possibility of commercial aquaculture in the long neglected semi-arid Karamoja sub-region of Uganda. The community in this area has been hugely dependent on livestock products which have become very scarce due to climate change consequences, and malnutrition is now rampant. Introducing commercial cage fish farming in the many man-made reservoirs/valley dams will augment economic development processes and supplement food and nutritional security of 
the vulnerable communities. Armed with the optimum stocking density of $100-150$ fishm $^{-3}$ of cage using high protein sinking feeds, the government of Uganda and other development partners may adopt these findings to guide formulation of regulatory policies for sustainable cage aquaculture in similar water bodies. Furthermore, the world has a number of semi arid areas and crater lakes with similar morphometric and environmental characteristics to Arechek valley dam and therefore, the commercialization of cage aquaculture in such areas may replicate and improve on this finding. Other than sinking feeds, more investigation needs to involve floating feeds and also other species in order to generate comprehensive results.

\section{Acknowledgements}

Financial support for this study was provided by the National Agricultural Research Organization-Uganda through the Agricultural Technology and Agri-business Advisory Services (ATAAS) project (P.109224). We sincerely acknowledge the Director of Research at Buginyanya Zonal Agricultural Research and Development Institute for providing the team with transport throughout the trials. Sincere appreciation to the field staff; Mr. Paul Lojok and Mr. Abura for guidance and coordination at the dam in Napak District. We thank $\mathrm{Mr}$ Gerald Woniala and Mr Martin Turyashemererwa for transport and ICT support respectively.

\section{Data Sharing Statement}

"Data pertaining to this manuscript is available in soft and hard copies within the National Agricultural Research Organization data management system" Any authority, organization, individual or organization interested in obtaining it in raw form may do so with express permission from the Director General using the addresses available in the following websites: Email: dgnaro@,naro.go.ug;Website: http://www.naro.go.ug

\section{Conflict of interests}

The authors have no conflict of interest whatsoever.

\section{Figure legends}

Figure 1 Map showing the location of Arechek valley dam where the experiment was conducted in Napaki district. Arechek dam location is marked pink on the map. The blue ribbons represent nearby streams and rivers while areas marked with star and yellow spots represent marketplaces and trading centres neighboring the site respectively. 
Figure 2 Trends in increase in weight of in five months growth period at Arechek Valley dam, Napaki district. The treatments were distributed in experiments units (cages A, B, C and D). Experiment A, B; C and D represent the different stocking densities 100, 150, 200 and 250 fishm $^{-3}$ respectively.

Figure 3 Trends in specific growth rates of Nile tilapia in five months growth period at Arechek Valley dam, Napaki district. The treatments were distributed in experiments units (cages A, B, C and D). Experiment A, B, C and D represent the different stocking densities $100,150,200$ and 250 fishm $^{-3}$ respectively.

Figure 4 Mean relative condition $( \pm$ Stdev) of Nile tilapia derived after regression of length and weight of individuals in each treatments data of all sampled individuals at Arechek Valley dam, Napaki district. The treatments were distributed in experiments units (cages A, B, C and D). Experiment A, B, C and D represent the different stocking densities 100, 150, 200 and 250 fishm $^{-3}$ respectively. Vertical bars represent \pm 1 standard deviation. Different letters above each treatment indicates significant differences at $\mathrm{P}<0.05$.

\section{REFERENCES}

[1] Alabaster JS, Lloyd R (1980). Water quality criteria for freshwater fish. London, Boston, Butterworth and Company Limited. 297pp. https://doi.org/10.1002/iroh.19810660329

[2] AOAC. (1995). AOAC. Official Methods of Analysis Association, Virginia,USA.AOAC Press., 771pp. http://www.sciepub.com/reference/141205.

[3] AOAC. (2005). Official methods of analysis, association of official analytical chemists. Gaithersburg, Maryland 20877-2417, USA, AOAC Press, 96pp. https://www.aoac.org/aoac_prod_imis/AOAC/Publications/Official_Methods_of_Analys is/AOAC_Member/Pubs/OMA/AOAC_Official_Methods_of_Analysis.aspx

[4] Ashley PJ (2007). Fish well-fare: current issues in aquaculture. Journal of applied animal behavior science 104(4): 199-235. http://dx.doi:10.1016/j.applanim.2006.09.001

[5] Atukunda G, State AE, Molnar J, Atekyereza P (2018). Aquaculture Development and Uganda's Agricultural Extension System: The Case of Fish Farmers in Central and Northern Regions. Journal of Fisheries Aquaculture Development. JFAD137. http://dx.doi:10.29011/2577-1493.100037 
[6] Barton BA, Iwama GK (1991). Physiological changes in fish from stress in aquaculture with emphasis on the response and effects of corticosteroids. Annual Review of Fish Diseases 1(1991): 3-26. https://doi.org/10.1016/0959-8030(91)90019-G.

[7] Bassey AU, Ajah PO (2010). Effect of three Feeding Regimes on Growth, Condition Factor and Food Conversion rate of Pond Cultured Parachanna obscura (Gunther, 1861) (Channidae) in Calabar, Nigeria. Turkish Journal of Fisheries and Aquatic Sciences 10(2):195-202. http://doi:10.4194/trjfas.2010.0206.

[8] Biswas G, Sundaray JK, Thirunavukkarasu AR, Kailasam M (2011). Length-weight relationship and variation in condition Chanos chanos (Forsskal, 1775) from tide-fed brackish water ponds of the Sundarbans- India. Indian Journal of fisheries 40(3):386390. http://doi.org/10.13140/RG.2.2.10685.46565.

[9] Bortone SA (2003). Biology of the spotted sea trout: CRC Marine Biology Series. Boca Raton-Florida, the United States of America. CRC Press., 328pp. https://www.crcpress.com/Biology-of-the-Spotted-Seatrout/Bortone/p/book/97808.

[10] Boyd CE (1998). Water quality for pond aquaculture: Research and Development. Auburn University, Alabama the United States of America. Series No.43. http://soiltesting.tamu.edu/publications/AU43.pdf.

[11] Cullis A (2018). Agricultural Development in Karamoja, Uganda: Recent Trends in Livestock and Crop Systems, and Resilience Impacts. Karamoja Resilience Support Unit, USAID/Uganda, UK aid, and Irish Aid, Kampala.

[12] Efitre J, Chapman LJ, Murie JD (2009). Fish condition in introduced tilapias of Ugandan crater lakes in relation to deforestation and fishing pressure. Environmental Biology of Fishes 85(2009): 63-75. http://doi:10.1007/s10641-009-9461-z.

[13] Ellis T, North B, Scott AP, Bromage NR, Porter M, Gadd D (2002). The relationships between stocking density and welfare in farmed rainbow trout. Journal of Fish Biology 61(3): 493-531. https://doi.org/10.1111/j.1095-8649.2002.tb00893.x.

[14] FAO (2009). Site selection criteria: General Fisheries Commission for the Mediterranean.Vigo (Spain)

[15]

AO (2017). Regional review on status and trends in aquaculture development in subSaharan Africa - 2015, by Benedict P. Satia. No.1135/4, Rome, Italy. : http://www.fao.org/3/a-i3720e.pdf. 
[16] Field AP, Wilcox RR (2019). Robust statistical methods: a primer for clinical psychology and experimental psychopathology researchers. Behavior Research and Therapy 2017(98): 19-38. https://doi.org/10.1016/j.brat.2017.05.013.

[17] Gonella H (2003). Snakeheads are aquarium fish. Aquarium Live 3(2003): 62-65. http://doi: 10.4194/trjfas.2010.0206.

[18] Greaves K, Tuene S (2001). The form and context of aggressive behaviour in farmed Atlantic halibut (Hippoglossus hippoglossus L.). Aquaculture 193(2001):139-147. www.elsevier.nlrlocateraqua-online

[19] Haylor GS (1991). Controlled hatchery production of Clarias gariepinus (Burchell 1822): growth and survival of fry at high stocking density. Aquaculture Research 22(4):405-422. https://doi.org/10.1111/j.1365-2109.1991.tb00754.x.

[20] Hecht T, Appelbaum S (1988). Observations on intraspecific aggression and coeval sibling cannibalism by larval and juvenile Clarias gariepinus (Clariidae: Pisces) under controlled conditions. Journal of Zoology 214(1): 21-44.

[21] Holm JC, Refstie T, Bo S (1990). The effect of fish density and feeding regimes on individual growth rate and mortality in rainbow trout (Oncorhynchus mykiss). Aquaculture 89(3-4): 225-232. https://doi.org/10.1016/0044-8486(90)90128-A

[22] Hossain MAR, Beveridge MCM, Haylor GS (1998). The effects of density, light and shelter on the growth and survival of African catfish (Clarias gariepinus) fingerlings. Aquaculture 160(3-4): 251-258. http://doi.org/10.1046/j.1365-2109.2001.00635.x

[23] Irwin S, O'Halloran J, FitzGerald RD (1999). Stocking density, growth and growth variation in juvenile turbot, Scophthalmus maximus (Rafinesque). Aquaculture 178(1): $77-88$.

[24] Lambert Y, Dutil JD (2001). Food intake and growth of adult Atlantic cod (Gadus morhua L.) reared under different conditions of stocking density, feeding frequency and size-grading. Aquaculture 192(2-4): 233-247.

[25] Le Cren ED (1951). The Length-weight relationship and seasonal cycle in gonad weight and condition in the perch (Perca fluviatilis). Journal of Animal Ecology 20(2):201-219. http://doi.org/10.2307/1540.

[26] Lloret J, Gil de Sola L, Souplet A, Galzin R (2002). Effects of large-scale habitat variability on condition of demersal exploited fish in the north-western Mediterranean. ICES Journal of Marine Science 59(6):1215-1227. http://doi:10.1006/jmsc.2002.1294

[27] Mondal A, Chakravartty D (2010). Grow-out performance, length-weight relationship and variation in condition of all male Nile tilapia (Oreochromis niloticus Linnaeus 1758) 
from low saline fertilize earthen ponds of Indian Sundarbans. International Journal of Biology Research 1(5): 28-33.

[28] Mortuza MG, Al-Misned AF (2013). Length-Weight Relationships, Condition Factor and Sex-Ratio of Nile Tilapia, Oreochromis niloticus in Wadi Hanifah, Riyadh, Saudi Arabia. World Journal of Zoology 8(1):106-109. http://doi:10.5829/idosi.wjz.2013.8.1.7247

[29] Ondhoro CC, Masembe C, Maes GE, Nkalubo WN, Walakira JK, Naluwairo J, Efitre J (2016). The condition factor, Length - Weight relationship and the associated parameters of Barbus altianalis (Boulenger, 1900) fishery in Lakes Victoria and Edward basins of Uganda. Environmental Biology of Fishes 100(2017):99-110. https://doi.org/10.1007/s10641-016-0540-7

[30] Rahman MA, Habib KA, Hossain A, Rayhan MZ, Azad SMO (2017). Impacts of stocking density and economic returns on the cage culture of stinging catfish, Heteropneustes fossilis. Intternational Journal of Fisheries and Aquatic Studies 5(4): $198-201$.

[31] Rayhan MDZ, Rahman MDA, Hossain MDA, Taslima A Tasmina A (2018). Effect of stocking density on growth performance of monosex tilapia (Oreochromis niloticus) with Indian spinach (Basella alba) in a recirculating. International Journal of Environment, Agriculture and Biotechnology 3(1):343-349. http://dx.doi.org/10.22161/ijeab/3.2.5.

[32] Ricker WE (1975). Computation and Interpretation of biological statistics of fish populations. Bulletin of Fisheries Board of Canada 191(94): 209-210.

[33] Sadek S (2013). Aquaculture site selection and carrying capacity estimates for inland and coastal aquaculture in the Arab Republic of Egypt. In L.G. Ross, T.C. Telfer, L. Falconer, D. Soto \& J. Aguilar-Manjarrez, eds. Site selection and carrying capacities for inland and coastal aquaculture, pp. 183-196. Available at: http://www.fao.org/3/a-i3322e.pdf

[34] Saillant E, Fostier A, Haffray P, Menu B, Laureau S, Thimonier J, Chatain B (2003). Effects of rearing density, size grading and parental factors on sex ratios of the sea bass (Dicentrarchus labrax L.) in intensive aquaculture. Aquaculture 221,183-206. http://doi.org/10.3906/zoo-0810-3

[35] Swift DR (1988). Aquaculture Training Manual. Fishing News Books Limited. London, $135 \mathrm{pp}$.

[36] Viadero RC (2005). Factors Affecting Fish Growth and Production. Water Encyclopedia. 3(2005):129-133. https://doi.org/10.1002/047147844X.sw241. 